\title{
Mechanism for the Formation and Development of Management Personnel Reserves for the Purposes of Ensuring the Innovative Development of the Defense Industrial Complex
}

\author{
Alexandr S. Mironov ${ }^{1 *[O R C I D ~ 0000-0002-4106-5519], ~}$ \\ Pavel G. Podgainii 1[ORCID 0000-0001-7177-8272]
}

\author{
${ }^{1}$ All-Russia Scientific and Research Institute "Center”, Moscow, Russia \\ mironov.scs@mail.ru
}

\begin{abstract}
The military-industrial complex (hereinafter - MIC) has always been and remains the most high-tech segment of the economy, occupying a leading place in the real sector. In addition to the most important function of ensuring the security of the state, the MIC is a source of positive qualitative changes in the civilian sectors of the economy. Of particular importance in this process is ensuring the continuity of the effective implementation of state policy in the field of defense, security and sustainable innovative development of MIC organizations, a key place in which is the training of management personnel. The article shows the importance and relevance of ensuring proper training for the leadership of the MIC and its place in the life cycle of personnel training in the interests of the MIC, a comparative analysis of various approaches to the formation of managerial personnel reserves used in the MIC. A unified approach to the formation and development of managerial personnel reserves in the MIC is proposed, on the basis of which, using the convergence methodology and structural and functional modeling, an appropriate organizational and economic mechanism is developed that describes a unified system of personnel reserves in the MIC, based on the integration of the existing personnel reserves of state corporations and integrated MIC structures within the framework of a unified multi-level system for the formation of managerial personnel reserves of the MIC at the federal and corporate levels. The main source of the initial data of scientific research and a tool for practical testing of the ideas proposed by the authors is the system tool created under the leadership of the Collegium of the Military-Industrial Commission of the Russian Federation for the training and appointment to target positions of leading personnel of the MIC - the Federal personnel reserve of the leadership of the MIC.
\end{abstract}

Keywords: personnel management, military-industrial complex, personnel reserve, managerial personnel, management personnel

\section{INTRODUCTION}

In modern conditions, it is important and urgent to increase the effectiveness of the implementation of state policy in the field of the military-industrial complex (hereinafter - MIC), including through the special nature of the organization of training and retraining of personnel. In order to ensure the continuity of the implementation of the state policy in the field of defense, security and sustainable innovative development of defense industry organizations, the creation of managerial personnel reserves (hereinafter - MPR) is of particular importance.

The problem of improving the quality of management is currently inextricably linked with the formation of appropriate competencies among managers, implying confident possession of management skills in a digital society, the ability to work using digital management technologies and effectively participate in vertical, horizontal and management structures aimed at solving problems such as target planning and strategic development. 
To solve the large-scale tasks facing the MIC, leaders of a new type are needed, who must:

- be able to professionally navigate in modern scientific, technical and technological trends;

- possess the best practices in strategic and project management, strategic marketing, financial and communications management, and have management skills in market conditions;

- have experience in participating in the implementation of projects to create technically complex products.

Also, the leaders of the MIC require knowledge of the specifics of management in the MIC in such areas as the formation of a unified system of initial data, the assessment of the feasibility of the state weapons program, mobilization training, standardization and quality assurance of military products, the budget process, and others.

Russian and foreign economists have accumulated significant experience in researching the problems of personnel management, training managers, creating personnel reserves and forming requirements for the professional qualities of managers. P.S. Assessorov analyzed the influence of the formation of a personnel reserve on the strategic development of an enterprise [1]. I.P. Marchenko, I.V. Marchenko note that the product of MPR creation is employees who are prepared to perform a managerial function at a professional level, and as a complex personnel technology, the institution of a personnel reserve in terms of potential capabilities is very capable of competing with the traditional form of "nurturing" management personnel based on the institution of substitution [2]. The role of innovative technologies in the formation of MPR is considered by N.S. Rychikhina, O.O. Korobova [3]. E.F. Zeer considers the problem of transprofessionalism - the ability of personnel to perform a variety of specialized activities, combining several professional qualifications acquired along different educational trajectories [4]. At the same time, foreign psychologist D. Levitin [5] notes that multitasking harms the employee, impairs memory, analytical and creative abilities contributes to a decrease in intelligence. D. Crenshaw, substantiating the effect of multitasking on the decrease in work efficiency and the deterioration of relationships with colleagues and family members, offers an effective method for switching between tasks [6]. The object of research by a number of scientists turned out to be representatives of Russian youth undergoing socialization and professionalization mainly in the Internet space, as a result of which a relationship was established between professional, value attitudes, strategies of Internet behavior and sociodemographic characteristics [7, 8]. The research team of the Russian State Vocational Pedagogical University proposed a model of an educational platform that combines advanced professional education (hereinafter - APE) with vocational training in order to ensure that the qualifications of graduates meet the constantly changing requirements of the labor market by the time they complete their studies and accelerate their career growth [9-12]

The above studies generally reflect the level of elaboration of individual problems in the corresponding research topic. However, a number of aspects of managing executive personnel of industrial enterprises, taking into account the specifics of the MIC in modern political and economic conditions, have not received comprehensive scientific coverage and practical solutions in the studies known to the authors.

The problematic of the studied area of formation and development MPR in the MIC consists in:

1) giving a special status to the training of management personnel in the interests of the MIC;

2) the fragmentation of infrastructural elements for working with MPR used in various corporations and integrated structures of the MIC;

3) the absence of the MIC as an object of management, unified approaches to working with MPR

\section{MATERIALS AND METHODS}

MPR is a group of managers and specialists with the ability to manage activities that meet the requirements for the positions of the personnel reserve. It is they who form the organization's development strategy and ensure its implementation.

The creation of a personnel reserve allows to ensure maximum predictability of personnel movement in the organization in accordance with the general concept of the organization's development strategy and, most importantly, to minimize the time, financial and other costs of finding new employees [3].

The purpose of this study is to develop an innovative approach, mechanism and method for 
creating MPR to ensure the continuity of the implementation of state policy in the field of defense, security and sustainable innovative development and an effective response of the MIC to modern threats.

To achieve this goal, the following tasks are performed:

1) the main stages of the life cycle of personnel training in the interests of the MIC are considered;

2) the place of training leaders in the life cycle of personnel training in the interests of the MIC is determined;

3) an analysis of the approaches to the formation of MPR used in the MIC is carried out;

4) a unified approach to the formation of the MPR is proposed;

5) an organizational and economic mechanism and a method for the formation and development of MPR in the MIC are being developed.

To obtain original data, an analysis was carried out of the relevant regulatory legal acts, materials of the meetings of the MIC collegium, the council of the MIC collegium on the development of the personnel potential of the MIC and annual meetings with the heads of personnel services of the defenseindustrial complex organizations, held by the Ministry of Industry and Trade of the Russian Federation (hereinafter referred to as the Ministry of Industry and Trade of the Russian Federation) on the basis of Federal State Unitary Enterprise "All-Russia Research Institute Center" (hereinafter - ARRI "Center"), as well as analysis of the results of surveys of heads of personnel services of state corporations and system-forming integrated structures of the MIC. The results of the analysis are the methodological basis of the study.

The work used a complex of scientific approaches, such as a systematic approach, methods of logical and comparative and analysis, structuralfunctional and logical-semantic modeling.

The fundamental basis of the study is the convergence methodology, which provides a synergistic effect of interaction between the methodological, technological and substantive processes of personnel training, as well as the training of leading personnel in the interests of the MIC.
The integrity and validity of the results obtained was, to a certain extent, influenced by the specifics of the functioning of the MIC, a significant part of the information about which is not of an open nature.

\section{RESULTS}

Leadership training in the personnel training life cycle

Currently, the life cycle of personnel training in the MIC includes the following processes.

1) Vocational guidance (for both applicants and students) - within the framework of this process, the ideas of the prestige of mastering specialties in demand in the MIC are promoted among young people. Examples are the WorldSkills championships held by the Union "Agency for the Development of Professional Communities and Workers" "Young Professionals (WorldSkills Russia)", career guidance events held by MIC organizations with students and applicants.

2) Targeted training - the implementation of this process is carried out within the framework of state plans for training personnel with secondary vocational and higher education for MIC organizations, as well as within the framework of targeted training in educational programs of secondary vocational and higher education.

3) Securing personnel in the MIC - this process is implemented, among other things, with the help of special conditions included in the agreements on targeted training, obliging graduates to work at the enterprises of the MIC with which such agreements are concluded, as well as social programs implemented by the organizations of the MIC. This process is also facilitated by the creation, in accordance with the research and production units of the Armed Forces of the Russian Federation, the personnel of which is formed from the number of workers of the defense industry organizations, called up for military service and continuing to work in the interests of the defense industry organizations, where they worked before conscription [10].

4) Mentoring - within the framework of this process, employees (mentors) of MIC organizations who are more experienced and 
qualified in a particular field of activity transfer knowledge, skills and abilities to the mentored.

5) Advanced training/continuing professional education - this tool is implemented within the corporate system of continuing professional education. Also, in most organizations of the MIC, carrying out scientific research, there are postgraduate studies, doctoral studies and dissertation councils.

Figure 1 shows the integration of leadership training into the life cycle of personnel training in the interests of the defense industry.

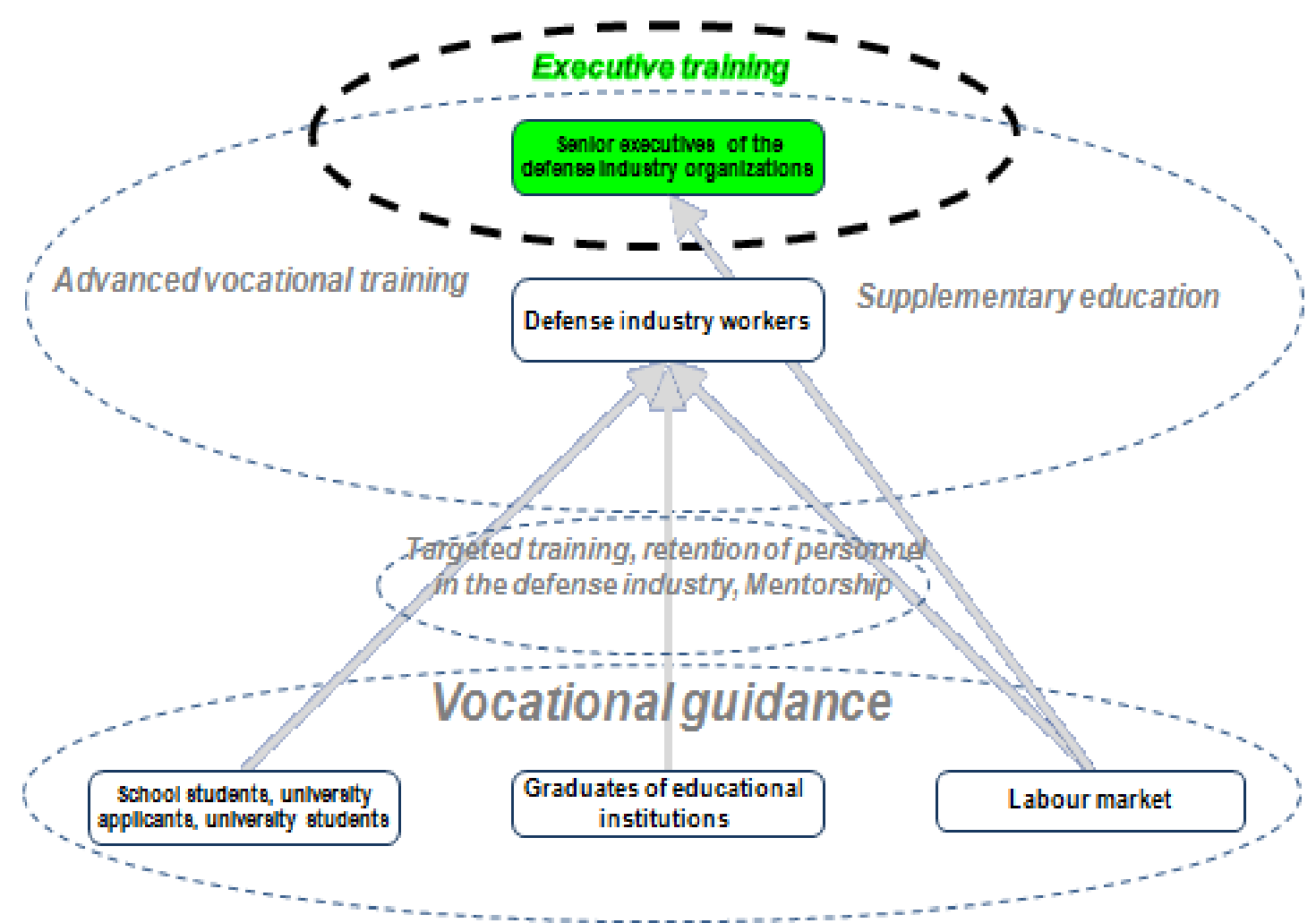

Figure 1. Training of MIC leaders in the life cycle of personnel training in the interests of the MIC Source: Compiled by the authors

Figure 1 shows that the training of defense industry leaders is a separate element of professional development/continuing professional education for employees of MIC organizations and is distinguished by its target orientation.

Analysis of approaches to the formation of MPR used in the MIC

At present, system tools for working with personnel reserves have been created at Tactical Missiles Armament (hereinafter - KTRV), Rosatom State Corporation (hereinafter - Rosatom) and Roskosmos State Corporation (hereinafter Roscosmos).

The specified personnel reserves are formed from the number of employees of organizations that are part of the corresponding corporations. At the same time, in Rosatom and Roskosmos, such a reserve is formed in order to protect each managerial position by the presence of successors with varying degrees of readiness, that is, for a specific need for a certain number of reservists.

Table 1 provides a comparison of these system tools for working with personnel reserves.

As one can see, in the KTRV in the procedure for forming the MPR there is no stage for determining the need for such a reserve.

In the MPR under consideration, there are the following main levels of target positions:

1) top executives - heads and deputy heads of the corporation and organizations within its sphere of activity;

2) mid-tier executives - heads of structural divisions; 
3) junior managers - managers who are subordinate to the heads of structural divisions.

Table 1. Comparative table of MPR

\begin{tabular}{|c|c|c|c|}
\hline \multirow[b]{2}{*}{$\begin{array}{c}\text { MPR Comparison } \\
\text { Criterion }\end{array}$} & \multicolumn{3}{|c|}{ Corporation } \\
\hline & $\underset{\underline{E}}{\mathbb{E}}$ & 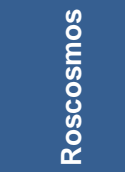 & $\frac{E}{\frac{1}{7}}$ \\
\hline $\begin{array}{l}\text { The presence of a } \\
\text { stage for determining } \\
\text { the need for MPR } \\
\text { before its formation }\end{array}$ & no & yes & yes \\
\hline $\begin{array}{l}\text { Creation of a reserve of } \\
\text { managers at the entry- } \\
\text { level management }\end{array}$ & no & no & yes \\
\hline $\begin{array}{l}\text { Age limit for joining the } \\
\text { MPR }\end{array}$ & $\begin{array}{l}55 \text { years } \\
\text { old }\end{array}$ & $\begin{array}{l}50 \text { years } \\
\text { old }\end{array}$ & no \\
\hline $\begin{array}{l}\text { Period of stay in the } \\
\text { MPR }\end{array}$ & $\begin{array}{l}\text { until the } \\
\text { age of } 55\end{array}$ & $\begin{array}{l}3 \text { to } 6 \\
\text { years }\end{array}$ & $\begin{array}{l}3 \text { to } 6 \\
\text { years }\end{array}$ \\
\hline $\begin{array}{l}\text { The presence of a } \\
\text { corporate academy for } \\
\text { training MPR } \\
\text { participants }\end{array}$ & no & yes & yes \\
\hline
\end{tabular}

Source: Compiled by the authors

In addition, Rosatom has an additional level of managers at the entry-level management, target positions in which are managers of sites, small laboratories, and senior project managers. The period of stay of these corporations in the MPR is limited and ranges from 3 to 6 years, depending on the level of the reserve.

At the same time, in the KTRV, the period of stay in the reserve of the top management, subject to mandatory re-certification, is limited only by the age of the reservist - 55 years, after reaching which there is an exclusion from the reserve.

It should be noted that Rosatom does not have an age qualification for inclusion in the MPR, while Roskosmos has it - 50 years old, while upon reaching the specified age, the reservist is not excluded from the reserve - the period of their stay in the reserve is limited on a general basis.

Training of MPR participants in the interests of Rosatom and Roskosmos organizations is carried out at ANO Corporate Academy of Rosatom and ANO Corporate Academy of Roskosmos, respectively.

At KTRV, training under a special program and raising the level of competencies of reservists is carried out by the corporation itself, and training for APE programs is carried out on a contractual basis with state educational organizations of higher professional education that have an appropriate license for this type of training. These talent pools are the main sources of filling vacant executive positions and the main tools for the career growth of employees in the corporations under consideration.

The tools for working with MPR in the considered corporations certainly do not cover the entire MIC. For example, the State Corporation Rostec (hereinafter - Rostec), which includes 460 MIC organizations (more than $36 \%$ of their total number), does not have such an instrument at all.

A unified approach to the formation and development of MPR in the defense industry

The system of professional training has always been a source of productive forces and intellectual resources of society. The crisis of world education, noted by Russian and foreign researchers, manifests itself in a growing discrepancy between the quality of vocational training and the needs of a modernizing society [10].

In order to ensure the development of unified approaches and the creation of a systematic tool for the selection, training and appointment of the most qualified heads of defense industry organizations, the MIC Collegium, together with the Ministry of Industry and Trade, Rosatom, Roskosmos and Rostec, with the participation of defense industry organizations, developed a methodological base, created an infrastructure and organized work on the creation of the Federal Personnel Center of the Military-Industrial Complex.

Candidates for the FPC of the MIC are selected from age groups up to 50 years old for targeted positions of heads of organizations and up to 55 years old - for scientific and technical leaders.

Methodological approaches to organizational work with the FPC of the MIC and the corresponding selection criteria are fixed in the Unified methodological materials on the formation and development of the FPC of the MIC, approved by the decision of the board of the MIC on February 26, 2020 [13].

The main criterion for the effectiveness of MPR is the appointment of its graduates to positions corresponding to the target. So, out of 55 people in the first recruitment of the FPC of the MIC, 5 people were appointed to target positions and 2 people changed their place of work with the transition to an equivalent position. Thus, the efficiency criterion is $12.7 \%$. In the future, it is expected to increase to $30 \%$ [13]. 
Organizational and economic mechanism for the formation and development of MPR in the MIC

In order to increase the interest of MIC organizations in the results of the implementation of measures for the formation and development of a systematic tool for working with MPR, it is necessary to ensure their participation in the financing of relevant activities.

If the selection and preparation of the first set of FPC of the MIC were carried out at the expense of the state program of the Russian Federation "Development of the military-industrial complex", then it was decided to finance the implementation of measures for the formation of the next set in the FPC of the MIC, including with the involvement of funds from organizations in the interests of which the training is carried out. participants of the FPC of the MIC [13].

The next logical stage in the development of the FPC of the MIC is building a unified system of reserves for the MIC, based on the integration of the existing personnel reserves of state corporations and integrated structures of the MIC within the framework of a single multi-level system for the formation of MPR at the federal and corporate levels (Figure 2).

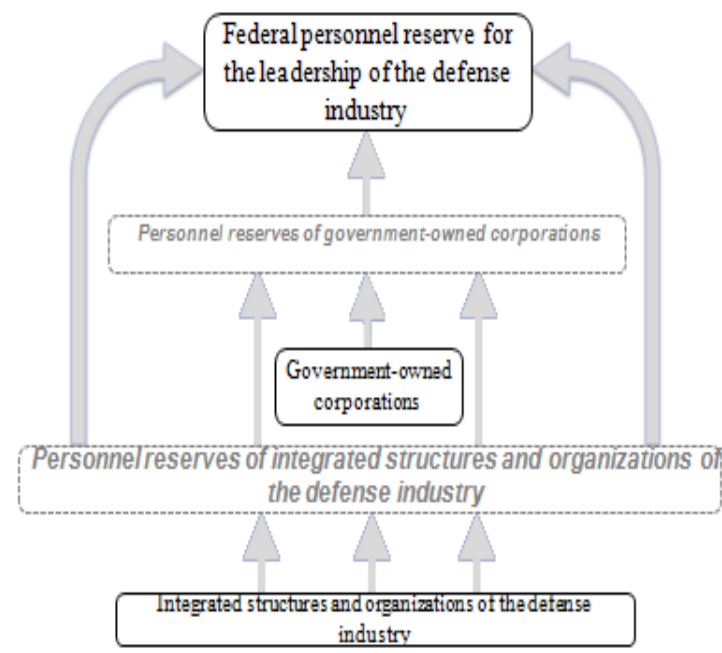

Figure 2. A unified multi-level system for the formation of the MPR

Source: Compiled by the authors

In this case, the FPC of the MIC will be the upper level of the unified system of personnel reserves, which will also include the personnel reserves of state corporations, integrated structures and organizations of the MIC.

Building the mechanism presented in Figure 2 will allow one to consider the training of participants in the FPC of the MIC as a measure of state support, complementing the corresponding corporate programs and allowing to reduce the costs associated with the training of managers.

Method for the formation and development of MPR in the MIC

In general, the method of formation and development of MPR in the MIC (Figure 3) consists of the following main stages.

1) Determination of the initial data of the created personnel reserve. This stage determines the target orientation of the personnel reserve: to fill which target positions and in which organizations the training of reservists will be carried out. Based on the initial data, it becomes possible to determine the amount of funding to ensure the training of participants in the personnel reserve.

2) Creation and development of a personnel reserve. At this stage, the selection of candidates for the personnel reserve is carried out according to predetermined criteria, appropriate bureaucratic procedures are carried out to include candidates in the personnel reserve, and the direct training of the participants in the personnel reserve is carried out.

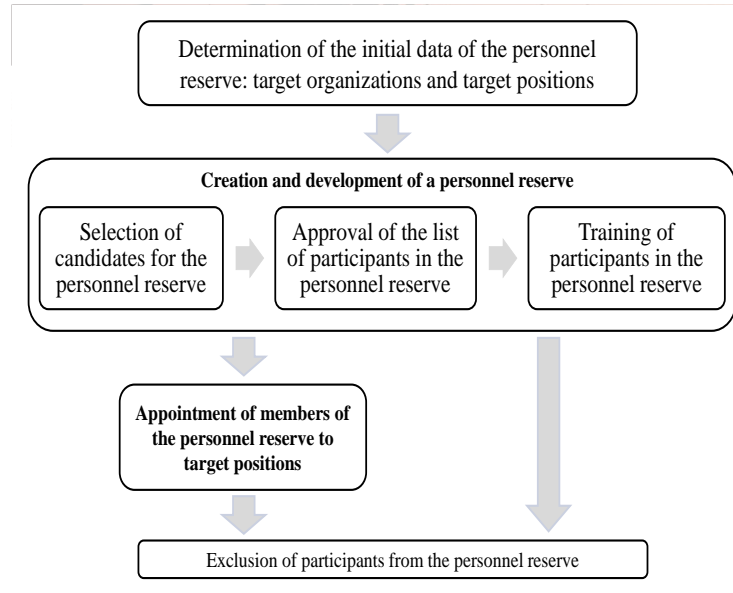

Figure 3. Method of formation and development of MPR

Source: Compiled by the authors

3) Appointment of members of the personnel reserve to target positions. This stage is the main one, but it does not always happen. Some of the participants in the personnel reserve will not be appointed to target positions for various reasons. 
4) Exclusion from the personnel reserve. This stage inevitably awaits all participants in the personnel reserve. They can be excluded both in connection with the appointment to the target position, and in connection with other circumstances.

As seen in Figure 3, the talent pool is a systemic tool that allows you to quickly form the competencies of candidates for appointment to leadership positions in accordance with the key requirements that the current political and economic situation dictates to leaders.

\section{DISCUSSION}

The proposed organizational and economic mechanism for the formation and development of MPR in the MIC is aimed at increasing the efficiency of training leaders, and is intended to complement the institution of substitution, since the appointment of participants in the Federal Personnel Center of the Military Industry Complex who have completed the training program is assumed in those MIC organizations where they are already filling managerial positions of a lower level.

The closest analogue of the FPC of the MIC considered in this study is the All-Russian competition for managers "Leaders of Russia", the main stages of which and the requirements for participants were studied by N.S. Rychikhina, O.O. Korobova. In particular, they revealed that when selecting candidates, special attention is paid to the leadership qualities of future reservists [3].

When considering candidates for inclusion in the FPC of the MIC, they have leadership qualities by default, since the FPC of the MIC is formed from those who are already filling managerial positions.

In addition, in the All-Russian competition for managers "Leaders of Russia", the emphasis is on the widest possible coverage of potential candidates, which is accompanied by a large number of eliminated candidates. So, in the competition in 2018-2020 out of 200 thousand applications, only 104 people won, in the competition in 2019-2020 out of 233.83 thousand applications - 106 people [3].

The FPC of the MIC selected 55 people out of 97 applications, i.e. the main emphasis is on preparation, and not on sifting everyone. Obviously, this is due to the much more modest financial and political capabilities of the parties interested in the creation of the FPC of the MIC.
According to P.S. Assessorov, the personnel reserve works effectively and is a real management tool only if it is included in a single personnel policy, begins to be created at the stage of creating a strategy, and is fully supported by managers [1]. This correlates with the fact that the issue of the formation of the FPC of the MIC is the object of special attention of the Collegium of the MIC and is being created under its leadership. In addition, the Government of the Russian Federation has approved the relevant Directives to ensure the appointment of participants in the FPC of the MIC to target positions [14].

\section{CONCLUSION}

In the course of the study, an innovative approach, mechanism and method for creating an managerial personnel reserve in the interests of the MIC have been developed.

To achieve this goal, the main stages of the life cycle of personnel training in the interests of the MIC were considered, where the place for training leaders was determined as a special type of additional vocational education.

Also, based on the analysis of approaches to the formation of MPR used in the defense industry, a unified approach to the formation of MPR was proposed and an organizational and economic mechanism and a method for the formation and development of MPR in the MIC were developed.

The study substantiates the point of view on the proposed organizational and economic mechanism for the formation and development of MPR in the MIC as a measure of state support that complements the corresponding corporate programs and allows one to reduce the costs of MIC organizations associated with the training of leaders.

At the same time, it was proposed to determine the Federal Personnel Center of the Military Industry Complex as the upper level of the unified system of personnel reserves, which also includes the personnel reserves of state corporations, integrated structures and organizations of the MIC.

Thus, the goal and objectives of the study were fulfilled in full.

The practical significance of the study lies in the possibility of applying the proposed methodological and practical recommendations in the field of personnel work of state corporations, integrated structures and organizations of the MIC. 
The introduction and use of the methodological apparatus for training leaders can improve the economic state of the MIC enterprises and ensure the achievement of state policy goals for the unconditional implementation of the state armament program, the dynamic development of scientific and technical, production, technological, human and intellectual potential of the MIC, and building up and realizing its competitive advantages in the long term perspective.

Promising directions for the development of this study are:

1) analysis of practical feasibility and development of the necessary measures to build a single multi-level system for the formation of MPR;

2) development of an optimal model of cofinancing by integrated structures and organizations of the MIC of a systemic tool for training executive personnel in their interests;

3) comparison of the systemic tool for training leaders in the interests of the MIC with other systemic tools for training leaders;

4) analysis of the prospective needs of integrated structures and organizations of the MIC in management personnel.

\section{AUTHORS' CONTRIBUTIONS}

Alexandr S. Mironov determined the main stages of the life cycle of personnel training in the interests of the defense industry, proposed a unified approach to the formation of MPR in the interests of the MIC and developed an organizational and economic mechanism for the formation and development of MPR in the MIC. Pavel G. Podgainii conducted an analysis of domestic and foreign publications on the topic of research and approaches to the formation of MPR used in the MIC, and also developed a method for the formation and development of MPR in the MIC.

\section{REFERENCES}

[1] P.S. Asessorov, Ye.N. Kartushina, "Formation of the staff reserve of the company as strategic task", Social-Economic Phenomena and Processes, 2013, vol. 5(51), pp. 31-34. (In Russ.).

[2] I.P. Marchenko, I.V. Marchenko, "Target approach to the preparation of a reserve of managerial personnel" [Tselevoy podkhod $\mathrm{k}$ podgotovke rezerva upravlencheskikh kadrov], State and Municipal Management. Scholar Notes, 2009, vol. 4, pp. 57-66. (In Russ.)

[3] N.S. Rychikhina, O.O. Korobova, "Innovative technologies of formation of the reserve of administrative staff", News of Higher Educational Institutions. The Series "Economics, Finance and Production Management", 2021, vol. 1(47). pp. 79-86. (In Russ.). DOI: 10.6060/ivecofin.20214701.520

[4] E.F. Zeer, E.E. Symanyuk, E.V. Lebedeva, "Transprofessionalism as a predictor for the preadaptation of an agent to the professional future", Siberian Journal of Psychology, 2021, vol. 79, pp. 89-107 (In Russ.). DOI: $10.17223 / 17267080 / 79 / 6$

[5] D. Levitin, "The organized mind: Thinking straight in the age of information overload", Moscow: Mann, Ivanov i Ferber, 2019, 544 p. (In Russ.).

[6] D. Crenshaw, "The myth of multitasking: How "doing it all" gets nothing done" [Mif o mnogozadachnosti], Moscow: Eksmo, 2010, 80 p. (In Russ.).

[7] E.V. Brodovskaya, A.Yu. Dombrovskaya, R.V. Pyrma, A.V. Sinyakov, A.A. Azarov, "The impact of digital communication on Russian youth professional culture: Results of a comprehensive applied study", Monitoring of Public Opinion: Economic and Social Changes, 2019, vol. 1(149), pp. 228-251. (In Russ.). DOI: 10.14515/monitoring.2019.1.11

[8] E.V. Brodovskaya, A.Yu. Dombrovskaya, I.A. Batanina, "The development of Russian youth digital citizenship: How to analyze and tackle the internet communication risks", in Proceedings of the IC "Internet and Modern Society", 2021, vol. 2813, pp. 337-349.

[9] E.F. Zeer, M.V. Zinnatova, V.S. Tretyakova, T.D. Bukovey, "Trans-professionalism as a predictor of adaptation of a person to digital professional future", Elementary Education Online, 2020, vol. 19(4), pp. 2532-2541. DOI: 10.17051/ilkonline.2020.764620

[10]E.F. Zeer, V.S. Tretyakova, M.V. Zinnatova, "Innovative model of socio-professional development of a student's personality", Education and Science Journal, 2020, vol. 22(3), pp. 83-115. (In Russ.). DOI: 10.17853/1994-5639-2020-3-83-115 
[11]E.F. Zeer, N.G. Tserkovnikova, V.S. Tretyakova, "Digital Generation in the Context of Predicting the Professional Future", Education and Science Journal, 2021, vol. 23(6), pp. 153-184. (In Russ.). DOI: 10.17853/1994-5639-2021-6-153-184

[12]E.P. Dyundik, S.S. Golubev, A.V. Makhova, L.D. Gurtskoy, "Development of human capital in the military-industrial complex of Russia in the context of digital transformation", in Proceedings of the ISPC "Environmental Risks and Safety in Mechanical Engineering”, 2020, vol. 217, p. 06005 . DOI: $10.1051 / \mathrm{e} 3$ sconf/202021706005

[13] "Minutes of the meeting with the first deputy chairman of the board of the Military-Industrial Commission of the Russian Federation
A.F. Elchaninov dated 23.03.2021 № AE-П79прВПК” [Protokol soveshchaniya u pervogo zamestitelya predsedatelya kollegii Voyennopromyshlennoy komissii Rossiyskoy Federatsii A.F. Elchaninova ot 23.03.2021 № AE-П79prVPK]. (In Russ.).

[14] "Directives to representatives of the interests of the Russian Federation for participation in meetings of the boards of directors (supervisory boards) of joint-stock companies with state participation dated 28.08.2020 № 7887П-П7” [Direktivy predstavitelyam interesov Rossiyskoy Federatsii dlya uchastiya v zasedaniyakh sovetov direktorov (nablyudatelnykh sovetov) aktsionernykh obshchestv s gosudarstvennym uchastiyem ot 28.08.2020 № 7887p-P7.]. (In Russ.). 